\title{
The revision of some results for Bernstein-Stancu type operators
}

\author{
DAN MiCLĂUŞ
}

\section{ABSTRACT.}

In the present paper the author revises some known results, respectively establishes new results for Bernstein-Stancu operators and for a particular case of the same operators, introduced first by L. Lupaş and A. Lupaş.

Department of Mathematics And COMPuter SCience

NORTH UNIVERSITY OF BAIA MARE

VICTORIEI 76, 430122 BAIA MARE, ROMANIA

E-mail address: danmiclausrz@yahoo.com 